\title{
HOT MONEY AND STOCK MARKET IN CHINA: EMPIRICAL EVIDENCE FROM ARDL AND NARDL APPROACHES
}

\author{
Kwang-Jing Yii* \\ Swinburne University of Technology, Sarawak Campus \\ Chai-Thing Tan \\ Universiti Tunku Abdul Rahman, Malaysia \\ Nian-Meng Tan \\ Universiti Tunku Abdul Rahman, Malaysia \\ Xue-Wen Teng \\ Universiti Tunku Abdul Rahman, Malaysia \\ Ting-En Khor \\ Universiti Tunku Abdul Rahman, Malaysia \\ Sui-Hang Fan \\ Universiti Tunku Abdul Rahman, Malaysia
}

\begin{abstract}
This study discusses the relationship between hot money and stock market in China by employing the Autoregressive Distributed Lag (ARDL) and Nonlinear Autoregressive Distributed Lag (NARDL) methods. The data used in this study is quarterly data over the period 2000: Q1 to 2017: Q4. The results show that oil price, economic growth and hot money possess a long-run relationship towards stock market in China, whereas, no effect is found from inflation. The oil price and economic growth are both positively related to stock market while there is a negative relationship from hot money. Furthermore, the study supports the existence of an asymmetric effect between hot money and stock market. The findings imply that policymakers should form better monitoring systems to control the inflow of hot money, thus, strengthening investors' confidence and avoiding unwanted bubbles in China's stock market.
\end{abstract}

Keywords: Hot money, Stock market, ARDL, NARDL, China.

Received: 21 November 2019

Accepted: 10 May 2021

https://doi.org/10.33736/ijbs.3753.2021

\footnotetext{
- Corresponding author: Faculty of Business, Design and Arts, Swinburne University of Technology, Sarawak Campus, Jalan Simpang Tiga, 93350 Kuching, Sarawak, Malaysia. Tel: +6082-260634 Email address: kyii@ swinburne.edu.my
} 


\section{INTRODUCTION}

In June 2018, there was a trade dispute between China and the US. The US accused China of "business theft" while China accused the US of other criminal offences. Donald Trump imposed higher levies and tariffs as a threat to China, in return China promised to fight back if the US continued its threats and if more tariffs were imposed. This spat brought a negative result to China's economy, where China's stock market recorded its steepest ever drop. The Shanghai Composite Index fell by $3.8 \%$ which was a record over two years. Besides over five months, China's currency, the Renminbi, also dropped to its lowest level against the US Dollar (Rushe, 2018).

Allen (2017) explains that the decline the stock market performance in China might have been caused by domestic political infighting. This infighting adversely affected the confidence of Chinese investors. The changing of China's leadership line-up made the situation even worse and increased uncertainties related to China's economic structural reforms. As time went by, these uncertainties increased, risking capital outflows from China's stock market in 2017.

China's stock market nowadays plays a significant role in the worldwide economy, as it is the second-largest stock market in the world (Amadeo, 2018). Mainland China has two main stock exchange indexes, namely; the Shanghai Stock Exchange and the Shenzhen Stock Exchange which are both used to stimulate China's economy. The Shanghai Stock Exchange ${ }^{1}$ is the largest stock market in mainland China and includes the majority of listed and larger companies. Besides, the Shanghai Stock Exchange is generally known as the blue-chip market of China. It comprises of three tiers, which are; the SSE 50 index, the SSE 180 index and the SSE 380 index (Shanghai Stock Exchange, 2019).

The SSE 50 index represents the fifty largest company stocks and is acknowledged as the "blue chip" index of the exchange. The SSE 180 index represents the top 180 equities, based on sector representation, size and liquidity, to better indicate the overall circumstances and movement of the Shanghai securities market. It also represents the performance reference point and infrastructure for financial derivatives. Moreover, the SSE 380 index comprises 380 stocks with middle size market capitalisation, high growth and profitability. This index intends to broadly indicate the efficiency of the new Shanghai blue chips.

On the other hand, hot money is commonly used in financial markets to indicate the flow of cash reserves, or financial assets, from one country to another to obtain a short-term profit on the difference in the interest rates or expected currency movements (Martin \& Morrison, 2008). These speculative capital flows are named "hot money" as they can shift very fast in and out of markets, which can potentially cause market instability. Hot money is considered an interesting issue for discussion in financial markets (Kim \& Iwasawa, 2017; Fuertes et al., 2016), as it expands around the globe, particularly in emerging markets, such as the Chinese market, due to globalisation. China is one of the largest emerging markets. After China reformed its exchange rate policy in 2005, the inflow and outflow of hot money became more frequent (Guo \& Huang, 2010). Figure 1 shows that China experienced a sharp change in hot money from 2000 to 2017.

\footnotetext{
${ }^{1}$ This study focuses on the Shanghai Stock Exchange, rather than the Shenzhen Stock Exchange, as the Shenzhen Stock Exchange is a smaller exchange. In comparison with the Shanghai Stock Exchange, the Shenzhen Stock Exchange is made up with a larger proportion of small and medium-sized organisations.
} 
Figure 1: Hot Money between 2000Q1 to 2017Q4 in China

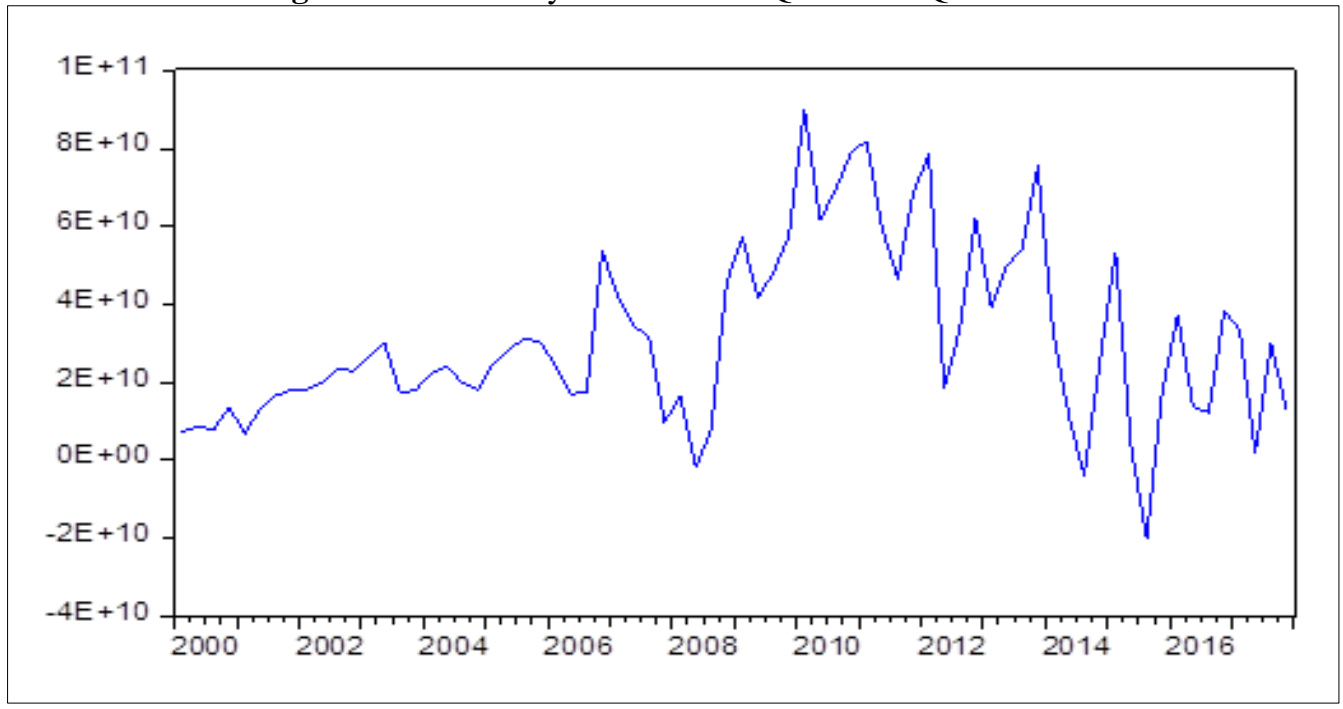

With the establishment of qualified foreign institutional investors (QFII) and qualified domestic institutional investors (QDII), the limits on capital flows have been relaxed, and foreign direct investment has been accelerated, which has activated the inflow and outflow of capital in China. Against this backdrop, the widely accepted view is that short-term speculative capital inflows, socalled "hot money", started in 2007, focusing on capital gains from increases in equity and property prices and the expected appreciation of the Renminbi (Tsuyuguchi, 2009).

Although the exact level of hot money flowing into China may be uncertain, there seems to be a consensus, which is why speculators are still transferring funds to China. There are two highlighted factors, which are; the relative interest rate in China and the United States and the assumption of the future appreciation of the value of China's currency, the Renminbi (RMB). The mixed effect of interest rate differences and the forecasted appreciation of the Renminbi is a powerful motivator for "hot money" to flow into China (Martin \& Morrison, 2008).

Hot money might be good for individuals but it also brings harm to stock market. China has encountered this kind of phenomenon frequently which causes upward pressure on stock prices. This leads to the occurrence of inflation, due to excessive foreign reserves, as a result of the net inflows of foreign capital without selling any goods. A surplus of foreign exchange indicates that overloaded spending on certain goods will lead to inflation, as the market will have high demand, but low supply (Wu, 2008).

Furthermore, Xiao et al. (2018) also explain how oil price shocks would affect changes in stock market volatility. Oil price shocks bring uncertainty to the financial sector as well as the economy and also negatively affect asset returns. Oil price shocks more easily affect the countries do not have fully formed economic policies together with immature investor such as China. Each oil price shock causes volatility for China's stock market as the cash flow of firms listed on the exchange is affected. Besides, the heterogeneous sensitivity and behaviour of investors towards oil price shocks 
will only enhance the negative effect of such shocks on stock returns. However, an increase in the oil price led to a drop in the trade values and price spreads set by firms who were price-makers from 2006 to 2011, based on US companies. The cost of trading will force to reduce due to the rise in oil prices, and directly affect a drop in market depth and depress following trade transaction. Therefore, a shock or rise in the oil price will increase China's stock market volatility and also decrease investors' levels of confidence (Zheng \& Su, 2017).

In China, the government declares that boosting different commodities, such as oil would stimulate economic growth with the support of infrastructure investments (Paraskova, 2018). It is important to include the oil price while investigating the stock market performance in China, as China overtook the United States as the largest global oil importer in the year 2017. China imported 39.46 million barrels of oil in April 2018 which helped them to deal the supply and demand issues that had occurred over the preceding months (Fickling, 2018). Besides, official Chinese customs data showed that China also cooperated with Iran, as China imported about 718,000 barrels a day on average, between January and May 2018 which exceeded a quarter of Iran's exported oil (Lavietes, 2018).

Other than that, a downturn in economic growth in China will highly affect the stock market performance. Borzykowski (2018) mentions that a slowdown in economic growth could bring a positive effect on China's stock market. Some economists also believe that the rate of growth in China will become slower in the future and suggest not to trust the official data regarding the GDP in China. This statement reflects upon the issues that occurred in January 2016, where market index, the S\&P China 500 declined by $10.5 \%$ because of the slowing of economic growth in China. This caused all investors, including the government of China, to fear that decreases in the growth rate may eventually affect the stock market performance.

Changes in the inflation rate will also bring an adverse effect on China's stock market. When there is an increase in the inflation rate, there is a decrease in profit for stock market investors. This is because an increase in the inflation rate indicates an increase in the risk of investing in stocks. The price that they need to pay will be higher, leading to lower stock returns. Furthermore, the expectations of investors decline as stock returns decrease which is also indicated by a reduction in stock yields (Bai, 2014). Besides, people's discretionary spending is reduced as they need to spend and consume at a higher cost, so they will choose not to invest, leading to negative performance in China's stock market (Tripathi \& Kumar, 2014).

Hot money also known as speculative funds, is money which flows into between countries in different directions seeking short-term profit. Hence, it tends to create worrisome bubbles and fluctuations in domestic stock markets, consequently impeding national economies. Thus, this study aims to examine the importance of hot money on the stock market performance in China, together with macroeconomic variables, such as GDP, oil price and inflation rate in the context of China by analysing the long-run symmetric and asymmetric effects. The remainder of this paper is organised as follows. Section 2 forms a literature review of existing studies. Section 3 explains the methodology utilised in this paper. The empirical results are discussed in Section 4, while Section 5 provides the conclusion to the study along with implications and a brief discussion on the limitations and possible future areas of study. 


\section{LITERATURE REVIEW}

Hot money refers to the flow of speculative funds, where such funds are invested into one country from another to earn a short-term profit on interest rate differences or predicted exchange rate shifts between the two countries (Fuertes et al., 2016). Hot money possesses a concept which states that a huge inflow of capital will affect stock prices. When huge inflows of hot money enter a country, this will drive up stock prices and will lead to the acceleration of stock market bubbles in a country (Wei et al., 2018).

There are only a limited number of studies that have examined the relationship between hot money and stock prices. Using the multivariate vector autoregressive (VAR) model to determine how hot money affected the stock market and real estate prices, Guo and Huang (2010) find that hot money contributes to a large portion of the volatility in the real estate market. The study states that stock prices experience a positive impact when encounter with a positive shock, but later they alternate between negative and positive impacts. This proves that speculative capital flowing into China will drive up share prices and incur stock market bubbles.

By investigating the impact of hot money on the volatility of China's stock market, Wei et al. (2018) apply the nonlinear Granger causality test and the GARCH - MIDAS model. Their findings reveal that the growth of hot money possesses a nonlinear causality on China's stock market. On the other hand, hot money is positively related to the long-term volatility of China's stock market in a time variant. The impact of hot money on several distinct periods, such as 2008 subprime debt crisis, 2010 European debt crisis, and 2015 Chinese stock market crash is analysed. However, the occurrence of these crises does not lead to spikes in the volatility of the stock market. This indicates that international capital flows are not the main reason for the massive volatility.

Much existing literature has studied the impacts of the oil price on the performance of stock markets, as oil price movements are a common determinant to forecast stock returns. Filis and Chatziantoniou (2014) find that the relationship between the oil price and stock market performance depends on whether a country plays the role of an oil exporter or importer. Increases in the oil price bring negative impacts to oil-importing stock markets while bringing positive impacts to oil-exporting stock markets. Oil importing countries tend to face a higher cost level of production during rises in the oil price. This decreases the level of consumption and leads to the poor performance of the stock market in oil-importing countries. Meanwhile, for oil-exporting countries, the levels of consumption and investment are raised, due to higher oil prices, leading to an improvement in their stock markets, as a result of the investment environment. This is supported by Wang et al. (2013) who conclude that there is a negative relationship between oil supply and stock markets in oil-importing countries and a significant effect of oil demand uncertainty in the stock markets of oil-exporting countries. Furthermore, oil price shocks lead to a trend of comovement in the stock markets of oil-exporting countries, as compared to oil-importing countries.

Economic growth plays a major factor in contributing to the performance of stock markets, as it measures the changes in a nation's GDP which represents the overall health of an economy. Evidence from Pakistan has demonstrated the impacts of the growth rate on the performance of the stock market. Nazir et al. (2010) reveal that economic growth has a positive impact on the stock market performance. The empirical result is supported by many researchers, who also find positive relationships between economic growth and stock market performance. Developed stock markets 
function in a way that increases savings and provide opportunities for investors to carry out productive investments that boost economic growth. The findings are consistent with Carp (2012), in Romania and Kirankabeş and Başarir (2012), in Turkey. However, Şentürk et al. (2014) state that there is no long-run relationship between economic growth and stock prices.

There have been several studies which have found a close relationship between stock prices and the inflation rate. Inflation may increase a firm's equity value, which might enhance company performance, leading to an increase in its stock price. Several studies have also proved that inflation has been positively related to stock prices (Tiwari et al., 2015; Ahmed et al., 2015; Breitung \& Candelon, 2006). In contrast, Asayesh and Gharavi (2015) find that there is a negative relationship between the inflation rate and stock prices. The negative relationship indicates that the relative lower expected real earnings growth affect companies which could not cover their costs which further decrease their future profitability. Similarly, Farooq and Ahmed (2018) explain that a high rate of inflation decreases the sensitivity of investment of stock prices which slows down stock market performance. Pearce and Roley (1985) study the response of stock price movements to the money supply, inflation, real economic activity and the discount rate by using and Autoregressive model with data from the year 1977 to 1982 . There is limited evidence stating that the inflation rate has an impact on the stock market performance.

Throughout previous literature reviews, the study of the relationship between hot money and stock market performance in China has been limited and open for debate. To fill this gap in the existing literature, the present study investigates the linear (ARDL) and asymmetric effects (NARDL) between hot money and stock market performance together with macroeconomic variables, such as GDP, oil price and inflation rate.

\section{METHODOLOGY}

\subsection{Data}

This study determines the relationship between hot money, GDP, oil price and inflation rate with stock market performance in China. The data is collected from Bloomberg and CEIC. This study uses quarterly time-series data from 2000: Q1 to 2017: Q4 with a total of 72 observations. The Asian Financial Crisis in 1997 led to the financial reform of China, especially the regulation of capital control measures to govern capital flows. However, capital flows were found to be augmented significantly after the 2000s (Cai et al., 2016). In 2008, there was an intense upsurge in the inflow of hot money through foreign capital that was hunting short-term profit. The amount of hot money increased from US\$500 billion to US\$1.75 billion (Martin \& Morrison, 2008). The data ranging from 2000-2017 generated robust findings, as it encompasses periods of large-scale hot money flows in China in 2003, the subprime debt crisis in 2008 and the collapse of the Chinese stock market in 2015 (Wei et al., 2018).

The Shanghai Composite Index (LNSM) is used as a proxy for stock market performance, Producer Price Index (LNINF) is used as the proxy for the price level, real Gross Domestic Product (RGDP) is used as the proxy for economic growth and oil price (LNOP) refers to the spot price of a barrel of crude oil in the crude oil market. Hot money refers to the flow of speculative funds or capital funds from one country to another. The objective of the flow of funds is mainly to gain a short- 
term profit on the difference in the interest rate or anticipated shifts in the exchange rate (Chari \& Kehoe, 2003). Since the flow of hot money is poorly monitored, there is no well-defined method to estimate the sum of hot money inflows into a country. According to Guo and Huang (2010), the estimated value of hot money can be obtained by the subtraction between foreign exchange reserve and the two different indicators which are; foreign direct investment, and trade and services. The use of higher frequency data is assumed to take greater account of fluctuations in hot money flows during stock market movements.

The formula for the estimation of hot money used in this study is expressed below:

$$
\mathrm{NHM}=F E R-F D I-T \& S
$$

where NHM is the value of hot money in USD, FER is the Foreign Exchange Reserves, FDI is Foreign Direct Investment and T\&S is the Trade and Services Balance. The data for these indicators are obtained from Bloomberg, except for trade and services. The data for trade and services are obtained by subtracting the data of imports from the data of exports. All of the data are transformed into natural logarithm series before analysis, except for the RGDP.

\subsection{ARDL Approach}

This study uses the Autoregressive Distributed Lag (ARDL) model, as proposed by Pesaran et al., 1999) to verify the long-run relationships for all of the different order of integration series, including non-stationary series. It also reparameterizes the result to the Error Correction Model (ECM) and implements the short-term dynamics and long-run relationships of the selected variables.

$$
\operatorname{LNSM}_{t}=\alpha_{0}+\alpha_{1} L N N H M_{t}+\alpha_{2} R G D P_{t}+\alpha_{3} L N O P_{t}+\alpha_{4} L N I N F_{t}+e_{t}
$$

where $L N S M_{t}$ is the stock market, $L N N H M_{t}$ is hot money, $R G D P_{t}$ is the real GDP, $L N O P_{t}$ is the oil price and $L N I N F_{t}$ is the inflation rate. $\alpha_{0}, \alpha_{1}, \alpha_{2}, \alpha_{3}, \alpha_{4}$ are the long-run parameters to be estimated and it is a white-noise error term.

\subsection{Nonlinear ARDL Approach (NARDL)}

Numerous studies have been conducted to examine the linear and long-run relationships between the stock market and its determinants using the ARDL model. Nonetheless, the ARDL model does not detect the non-linear relationship that considers positive and negative changes in economic or political agents to respond to positive or negative occurrences (Tursoy et al., 2018). Therefore, it is vital to employ the NARDL approach as a complement to the ARDL model (Faisal et al., 2018; Luqman \& Kouser, 2018; Salim \& Shi, 2019). The NARDL model is designed to create a simultaneously asymmetric non-linear autoregressive model and to create a cointegration of the chosen variables in a single equation model. It is an asymmetric extension to the ARDL model which is designed to capture both the long-run and short-run asymmetries in a variable of interest. We adopt this modelling approach for our purpose. 


$$
\begin{gathered}
L N S M_{t}=\alpha_{0}+\alpha_{1} L N N H M_{-} \mathrm{P}_{t}+\alpha_{2} L N N H M_{-} \mathrm{N}_{t}+\alpha_{3} R G D P+\alpha_{4} L N O P_{t} \\
+\alpha_{5} L N I N F_{t}+e_{t}
\end{gathered}
$$

where $L N N H M_{-} \mathrm{P}_{t}$ and $L N N H M_{-} \mathrm{N}_{t}$ represent the partial sums of the positive and negative changes in $L N N H M_{t}$ which can be derived as follows:

and

$$
L N N H M_{-} \mathrm{P}_{t}=\sum_{i=1}^{t} \Delta L N N H M_{-} \mathrm{P}_{t}=\sum_{i=1}^{t} \max \left(\Delta L N N H M_{-} \mathrm{P}_{i}, 0\right)
$$

$$
L N N H M_{-} \mathrm{N}_{t}=\sum_{i=1}^{t} \Delta L N N H M_{-} \mathrm{N}_{t}=\sum_{i=1}^{t} \max \left(\Delta L N N H M_{-} \mathrm{N}_{i}, 0\right)
$$

With a possible asymmetric effect, this hypothesis can be tested by evaluating $\alpha_{1}$ and $\alpha_{2}$ in Equation (3) as it captures the effect of positive and negative changes in hot money on the stock market performance, respectively. There would be no asymmetry found between hot money and stock market performance if $\alpha_{1}=\alpha_{2}$, however, if $\alpha_{1} \neq \alpha_{2}$ then the presence of a nonlinear relationship could be concluded. Thus, Equation (3) reflects the asymmetric long-run hot money pass through to the stock market.

By rewriting Equation (3) in an ARDL setting, based on Pesaran and Shin (1998) and Pesaran et al. (2001), the equation below can be specified:

$$
\begin{array}{rl}
\Delta L N S M_{t}=\alpha+\beta_{0} & L N S M_{t-1}+\beta_{1} R G D P_{t-1}+\beta_{2} L N O P_{t-1}+\beta_{3} L N I N F_{t-1}+\beta_{4} L N N H M_{-} P_{t} \\
& +\beta_{5} L N N H M_{-} \mathrm{N}_{t}+\sum_{i=1}^{q} \varphi_{i} \Delta L N S M_{t-i}+\sum_{i=0}^{q} \gamma_{i} \Delta R G D P_{t-i}+\sum_{i=0}^{s} \gamma_{i} \Delta L N O P_{t-i} \\
& +\sum_{i=0}^{q} \gamma_{i} \Delta L N I N F_{t-i}+\sum_{i=0}^{s}\left(\theta_{i}^{+} \Delta L N N H M_{-} \mathrm{P}_{t-i}+\theta_{i}^{-} \Delta L N N H M_{-} \mathrm{N}_{t-i}\right)+u_{t}
\end{array}
$$

The long-run impact of hot money increases and decreases on the performance of the stock market was represented by $\alpha_{1}=-\beta_{4} / \beta_{0}$ and $\alpha_{2}=-\beta_{5} / \beta_{0}$, respectively. On the other hand, $\sum_{i=0}^{s} \theta_{i}^{+}$measures the short-run influences of hot money increases on the stock market, while $\sum_{i=0}^{s} \theta_{i}^{-}$measures the short-run influences of hot money decreases on the stock market. Hence, in addition to the asymmetric long-run relationship, the asymmetric short-run influences of hot money changes on the stock market are also captured in Equation (6). Furthermore, to check the performance of the estimated model, several diagnostic tests, such as multicollinearity, serial correlation, normality, functional form and heteroscedasticity are carried out.

\subsection{VECM Granger Causality}

Lu and Xin (2010) state that the Granger causality test is an approach for deciding whether a onetime series helps in estimating another. Two tests are implemented which are; the F-type Granger causality test and a Wald- type test which tested for a non-zero correlation between the error processes of the cause and effect variables. If every variable is integrated at order one, I(1), it would indicate that the cointegration test could take place to determine if there is a cointegrating 
relationship between the variables. If cointegration existed, the Granger causality test is then conducted, based on the Vector Error Correction Model (VECM).

Suharsono et al. (2017) state that the VECM refers to a form of restricted Vector Autoregressive model, due to the presence of non-stationary data, which is cointegrated, therefore, the extra restriction must be given. The VECM will be applied using the cointegration restriction data into the specifications. This explains why the VECM is usually referred to as a VAR design for nonstationary series, which consist of cointegrating relationships. After cointegration has been recognised, the error correction method can take place for test processing. When differences show in the degrees of integration between the variables that have been tested, the test will be completed jointly between long term equations with the error correction equation, after the recognition of the availability of the cointegration variables. The degree of integration for cointegrated variables is known as multi cointegration. Nevertheless, if no cointegration is found, the test will continue by taking the first difference of the variable. The steps in the VECM also determine the length for the lags that test for the Granger causality. After that, the degree of the cointegration is tested and the VECM estimated, lastly the variance is decomposed.

\subsection{Impulse Response Function}

Haan (2011) states that the impulse response function states a j-period response when one system is shocked by a one-standard-deviation shock. It is defined as $\operatorname{IRF}(j)=\tilde{Y}_{\tau-1+j}-\bar{Y}_{\tau-1+j}$. In linear processes, the impulse response function is independent of particular draws for $\bar{\varepsilon}_{\mathrm{t}}$. Therefore, it begins at a steady state where $\varepsilon_{t}$ has been zero for a long time. The equation of IRF in the linear

process is $\operatorname{IRF}(j)=\sigma \rho^{j-1}$. The impulse response function in this process belongs to non-stochastic one. However, in theoretical models, it is not important to obtain the impulse response function by giving one standard deviation shock to the system when the policy function has been settled. The shocks included in the model are structural shocks, such as productivity shocks, preference shocks, and monetary policy shocks. The reduced form vector autoregressive model (VAR) is a useful forecasting model and the structural VAR model is used to back out the structural shocks. Lu and Xin (2010) highlight that the VAR model is expressed in vector MA( $\infty)$ form as $y_{t}=\mu+\varepsilon_{t}+\Psi_{1}$

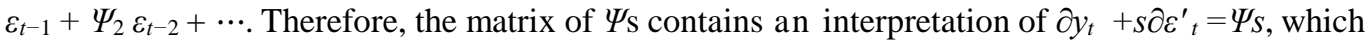
indicates that the row $i$ and column $j$ elements of $\Psi_{\mathrm{s}}$ analyse the result of raising in one unit in $j$-th variable's innovation at time $\mathrm{t}\left(\varepsilon_{j t}\right)$ for the number of $i$-th variables at date $\mathrm{t}+\mathrm{s}\left(y_{i t+s}\right)$, holding all of the other innovations at all times constant.

\subsection{Variance Decomposition}

Variance decomposition is a classical statistical method which can uncover simplifying structures in large numbers of variables, which is also known as multivariate analysis. This method can more precisely be called forecast error variance decomposition and is used in vector autoregressive models (VAR) to interpret the relationship between the variables. It measures the proportion of the movements of a variable due to shocks to the variable itself and shocks to other variables. VAR models are formed as follows:

$$
Y_{t}=-A \imath Y_{t-\imath}+\ldots+A \rho Y_{t-\rho}+\mu_{t}
$$


In Equation (7), the variables are mainly endogenous and it is hard to untie the relationship between them fromthe coefficient matrices. Hence, variance decomposition helps to interpret the VAR models. In the recursive orders, all of the one period forecast-error variance of $\mathrm{Y}$ is due to mean $(\mu)$. Over a longer horizon, the explanatory variables of $\mu$ will diminish. This means that the variance of the forecast error increases with the horizon (Lutkepohl, 2010).

\section{EMPIRICAL RESULTS}

\subsection{Descriptive Statistics}

Table 1 shows the descriptive statistics for the variables. The mean of hot money amounted to USD 28.080 billion with a standard deviation of USD 0.941 billion in China. Hot money reaches as high as USD 28.998 billion in the fourth quarter of 2016. This is because speculative capital flows shift very fast in and out of China's markets, which is likely to cause instability in China's stock market. According to Allen (2017), the foreign exchange reserves in China declines to USD 3.01 trillion due to the Trump factor, where the US has implemented higher tariffs on China. Besides, the average of the stock market is recorded as USD 7.795 billion with a standard deviation of USD 0.378 billion in the Shanghai Composite Index. Regarding economic growth in China, the maximum and minimum values are amounted to $15.00 \%$ and $6.70 \%$ in real GDP, respectively. Moreover, the oil price and inflation rate deliver means of USD6.114 billion of WTI and USD 0.797 billion of PPI, respectively. The standard deviation is amounted to USD 0.462 billion of WTI and USD 0.665 billion of PPI, respectively.

Table 1: Descriptive Statistics

\begin{tabular}{llcclc}
\hline \hline & $\begin{array}{l}\text { Stock Market } \\
\text { (Shanghai } \\
\text { Composite } \\
\text { Index, USD }\end{array}$ & $\begin{array}{l}\text { Hot Money } \\
\text { (USD billion) } \\
\text { billion) }\end{array}$ & $\begin{array}{l}\text { Oil Price (West } \\
\text { Texas } \\
\text { Intermediate } \\
\text { (WTI), USD } \\
\text { billion) }\end{array}$ & $\begin{array}{l}\text { Economic } \\
\text { Growth (Real } \\
\text { GDP in } \\
\text { percentage) }\end{array}$ & $\begin{array}{l}\text { Inflation } \\
\text { (Producer } \\
\text { Price Index, } \\
\text { USD billion) }\end{array}$ \\
\hline $\begin{array}{l}\text { Mean } \\
\text { Standard }\end{array}$ & 7.795 & 28.080 & 6.114 & 9.421 & 0.797 \\
$\begin{array}{l}\text { Deviation } \\
\text { Maximum }\end{array}$ & 0.378 & 0.941 & 0.462 & 2.309 & 0.665 \\
Minimum & 8.670 & 28.998 & 6.746 & 15.00 & 2.116 \\
\hline \hline
\end{tabular}

Table 2 presents the results of the Augmented Dickey-Fuller (ADF) and Phillips-Perron (PP) unit root tests for the five variables, both at the level form and the first difference with the intercept, as well as intercept and trend. Interestingly, both the ADF test and the PP test show that all the variables are non-stationary in their intercept at level form, except for hot money and inflation. Whereas, under the intercept and trend, all of the variables under the PP test are non-stationary, while the variables under the ADF test are also non-stationary, except for inflation which is stationary at the $1 \%$ significance level.

At the first difference level under the ADF test, all of the variables are found to be stationary at the $1 \%$ significance level, except for hot money which is non-stationary at the intercept. However, all of the variables are stationary at the intercept and trend. On the other hand, all of the variables are 
found to be integrated at $I(1)$ under the PP test, at both the intercept as well as at the intercept and trend. As the variables are found to have the order of $I(0)$ and $I(1)$, the ARDL bounds test is employed to determine the long-run cointegration between hot money, oil price, RGDP, inflation rate and stock market in China.

Table 2: Unit Root Tests

\begin{tabular}{|c|c|c|c|c|}
\hline \multirow[t]{2}{*}{ ADF } & \multicolumn{2}{|r|}{ Level } & \multicolumn{2}{|c|}{ First Difference } \\
\hline & Intercept & Intercept and Trend & Intercept & Intercept and Trend \\
\hline LNSM & -2.1327 & -2.9138 & $-6.6647 * * *$ & $-6.6245 * * *$ \\
\hline LNNHM & $-3.7833 * * *$ & 1.9970 & -1.2755 & $-6.2659 * * *$ \\
\hline RGDP & -1.7943 & -2.3611 & $-7.9822 * * *$ & $-7.9578 * * *$ \\
\hline LNOP & -1.7739 & -1.5750 & $-7.1247 * * *$ & $-7.1295 * * *$ \\
\hline LNINF & $-4.5966 * * *$ & $-4.4443 * * *$ & $-3.6544 * * *$ & $-3.5548 * *$ \\
\hline \multirow[t]{2}{*}{$\mathbf{P P}$} & \multicolumn{2}{|r|}{ Level } & \multicolumn{2}{|c|}{ First Difference } \\
\hline & Intercept & Intercept and Trend & Intercept & Intercept and Trend \\
\hline LNSM & -2.0676 & -2.7119 & $-6.7148^{* * * *}$ & $-6.6743 * * *$ \\
\hline LNNHM & $-3.5343 * * *$ & 1.4870 & $-3.4692 * *$ & $-6.2385 * * *$ \\
\hline RGDP & -1.9250 & -2.4851 & $-7.9985 * * *$ & $-8.0255 * * *$ \\
\hline LNOP & -1.7993 & -1.6465 & $-7.0188 * * *$ & $-7.0299 * * *$ \\
\hline LNINF & $-3.1470 * *$ & -3.0806 & $-7.7924 * * *$ & $-7.8934 * * *$ \\
\hline
\end{tabular}

Notes: $* * *, * *$ and $*$ denote the significance at the $1 \%, 5 \%$ and $10 \%$ levels, respectively.

\section{$4.2 A R D L$}

Table 3 presents the results of the ARDL bounds test, based on the stock market and its determinants. The ARDL $(1,0,0,0,3)$ model is selected to fit the data of stock market performance. The optimal lag is selected based on the Akaike information criterion (AIC) estimator. The computed F-statistic of 5.5829 in the ARDL bounds test is greater than the upper critical bound value of 5.548 at the $1 \%$ significance level (Narayan, 2005). The rejection of the null hypothesis of no cointegration suggests the existence of a steady and long-run relationship among hot money, oil price, inflation rate, RGDP and stock market in China. This is in line with several previous findings, such as Ahmed et al. (2015), Kirankabeş and Başarir (2012) and Wei et al. (2018). Panel A in Table 4 shows the long-run relationship between the variables and stock market. As indicated, hot money and the RGDP are positive and statistically significant with the stock market. This is consistent with the earlier studies conducted by Wei et al. (2018), Nazir et al. (2010) and Carp (2012). The oil price shows a statistically negative effect on the stock market, which is consistent with Wang et al. (2013). Our results show that inflation has no significant relationship with the stock market. Generally, monetary policy mainly stabilises commodity prices in the market while stock market volatility would be stabilised through a self-reinforcing soothing effect via other factors (Uwubanmwen \& Eghosa, 2015; Pearce \& Roley, 1985).

The robustness of the model is confirmed by several diagnostic tests, as shown in Panel B of Table 4, such as autoregressive conditional heteroskedasticity (ARCH), Breusch-Godfrey serial correlation Lagrange multiplier (LM) Jarque-Bera test and Ramsey RESET. The Breusch-Godfrey serial correlation LM test indicates that there is no serial correlation problem in the model while the Jarque-Bera test shows that the data in the model is normally distributed. Moreover, the heteroscedasticity test also shows that no heteroskedasticity problems are found. Besides, the results 
of the cumulative sum (CUSUM) and CUSUM of squares (CUSUMSQ) tests are shown in Figure 2. The Ramsey RESET test indicates that the model does not have any functional form misspecification. Furthermore, the plots of the CUSUM and CUSUMSQ tests in Figure 2 also point out that there is no structural instability of the long-run and short-run estimated parameters in the sample period. These results imply that the estimated parameters of the model produce a reliable estimation.

Table 3: Bounds Test Results

\begin{tabular}{lccc}
\hline \hline \multicolumn{1}{c}{ Model } & \multicolumn{2}{c}{ F-statistic } & \\
\hline LNSM=f(LNNHM,LNOP,RGDP, LNINF) & & $5.5829^{* * *}$ & \\
Optimal Lag & & & \\
\hline Critical Value & & & $I(0)$ \\
\hline $1 \%$ significance level & 4.168 & & 5.548 \\
$5 \%$ significance level & 3.042 & & 4.244 \\
$10 \%$ significance level & 2.558 & & 3.654 \\
\hline \hline
\end{tabular}

Table 4: ARDL Model Results

\begin{tabular}{lcl}
\hline \hline Panel A: Long-run Relationship & & \\
\hline \multicolumn{1}{c}{ Variable } & Coefficient & Probability \\
\hline C & -21.864 & $0.0019^{* * *}$ \\
LNNHM & 1.116 & $0.0000^{* * *}$ \\
LNOP & -0.576 & $0.0804^{*}$ \\
RGDP & 0.226 & $0.0042^{* * *}$ \\
LNINF & -0.476 & 0.1903 \\
\hline Panel B: Diagnostic Checking & F-Statistic & Probability \\
\hline LM test & 0.0248 & 0.8757 \\
ARCH Test & 0.0964 & 0.7576 \\
Ramsey RESET & 0.2492 & 0.6203 \\
Jarque-Bera Test & 2.0848 & 0.3526 \\
\hline \hline
\end{tabular}

Notes: Critical values: case III: unrestricted intercept and no trend $(\mathrm{k}=4, \mathrm{~T}=75)$.

( ) refers to p-values, $* * *, * *$ and $*$ denote the significance at the $1 \%, 5 \%$ and $10 \%$ levels, respectively.

Figure 2: Plot of the cumulative sum (CUSUM) and CUSUM of Squares Tests for the ARDL Equation of Stock Market Performance

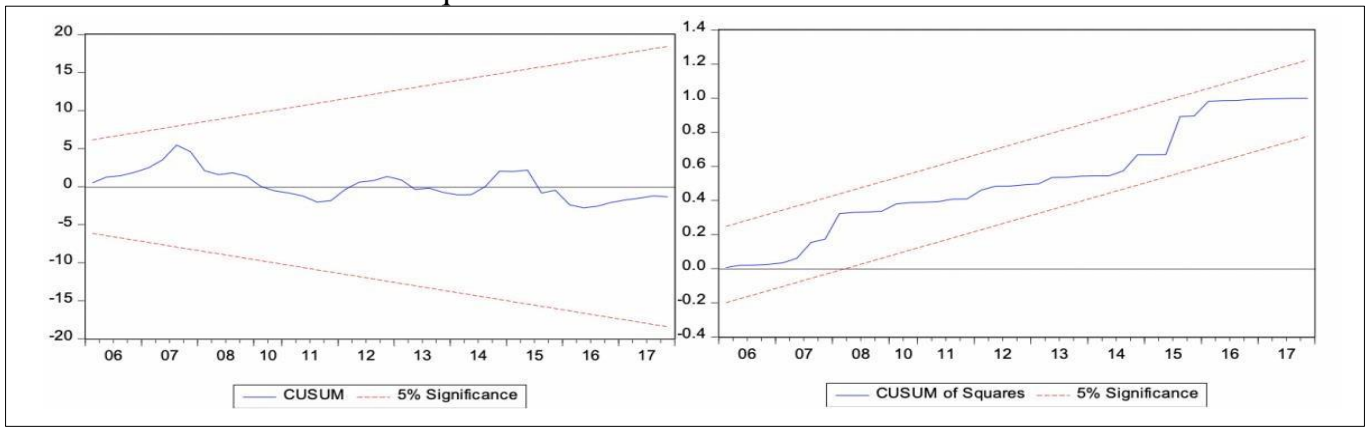




\section{$4.3 \quad N A R D L$}

Panel A in Table 5 shows the final specification of the NARDL model by trimming insignificant lags. From the results in Panel A, we compute the long-run equations, as shown in Panel B. The results show that China's stock market performance is significantly increased by 6.28 per cent when there is a one per cent decrease in hot money. This indicates that China's stock market performance does not entirely rely on international capital inflows, whereby, reducing hot money but emphasising domestic industries could also assist in raising stock prices.

Meanwhile, positive changes in hot money do not significantly influence the stock market performance (Jansen, 2003). China's stock market is mainly dominated by several stock indices, such as industry, commerce, public utilities and real estate (Wei et al., 2018). The insignificant effect might be due to the inflow of hot money not being directed to the stock market but another investment channel, namely the real estate market. The fundamentals of listed real estate companies would not capture the immediate effect from the market towards their stock price. Foreign investors who aim for short-term profits will withdraw their capital from a country promptly.

The different results imply that the pass-through of hot money to the stock market performance is incomplete. This might have been due to a bullish or bearish market as well as financial booms or crises that cause extreme volatility in stock prices (Chari \& Kehoe, 2003; Domowitz et al., 1997). On the other hand, both the oil price and economic growth are positively related to the stock market performance, while inflation does not affect the stock market performance. Panel $\mathrm{C}$ of Table 5 supports that an asymmetric effect existed between hot money and stock market performance in the long run. This is in line with the findings of Guo and Huang (2010) who state that hot money would alternate the changes between negative and positive directions.

The estimations are also examined through several diagnostic tests and the results are reported in Panel D of Table 5. The diagnostic tests include ARCH, LM and Ramsey RESET. Figure 3 displays the CUSUM and CUSUMSQ statistics to test the structural stability of the model. The results show that the model passes all of the diagnostic tests which support that the model is normally distributed and with the absence of autocorrelation and heteroskedasticity, and has parameter stability.

Table 5: Nonlinear ARDL Estimation Results

\begin{tabular}{lll}
\hline \hline Panel A: Nonlinear ARDL & & \\
\hline \multicolumn{1}{c}{ Variable } & Coefficient & Probability \\
\hline C LNSM (-1) & -2.5679 & $0.0541^{*}$ \\
LNNHM_P (-1) & -0.3396 & $0.0038^{* * *}$ \\
LNNHM_N (-1) & -0.1093 & 0.4480 \\
LNOP (-1) & -2.1327 & $0.0121^{* *}$ \\
RGDP (-1) & 0.7447 & $0.0047^{* * *}$ \\
LNINF (-1) & 0.0787 & $0.0003^{* * *}$ \\
\hline Panel B: Long-run Relationship & -0.1115 & 0.1384 \\
\hline C & Coefficient & Probability \\
LNNHM_P & -7.5624 & 0.1378 \\
LNNHM_N & -0.3220 & 0.4798 \\
& -6.2807 & $0.0178^{* *}$
\end{tabular}




\begin{tabular}{lll} 
LNOP & 2.1931 & $0.0217^{* *}$ \\
RGDP & 0.2317 & $0.0026^{* * *}$ \\
LNINF & -0.3283 & 0.2391 \\
\hline Panel C: Asymmetric Test & & \\
\hline$\alpha_{3}=\alpha_{4}$ & 8.3673 & $0.0082^{* * *}$ \\
\hline Panel D: Diagnostic Checking & F-Statistic & Probability \\
\hline LM test & 1.8745 & 0.1565 \\
ARCH Test & 2.316 & 0.1338 \\
Ramsey RESET & 0.1865 & 0.6701 \\
Jarque-Bera Test & 2.3160 & 0.3141 \\
\hline \hline
\end{tabular}

Notes: Critical values: case III: unrestricted intercept and no trend $(\mathrm{k}=4, \mathrm{~T}=75)$.

( ) refers to p-values, $* * *, * *$ and $*$ denote the significance at the $1 \%, 5 \%$ and $10 \%$ levels, respectively.

Figure 3: Plot of the cumulative sum (CUSUM) and CUSUM of Squares Tests for the NARDL Equation of Stock Market Performance

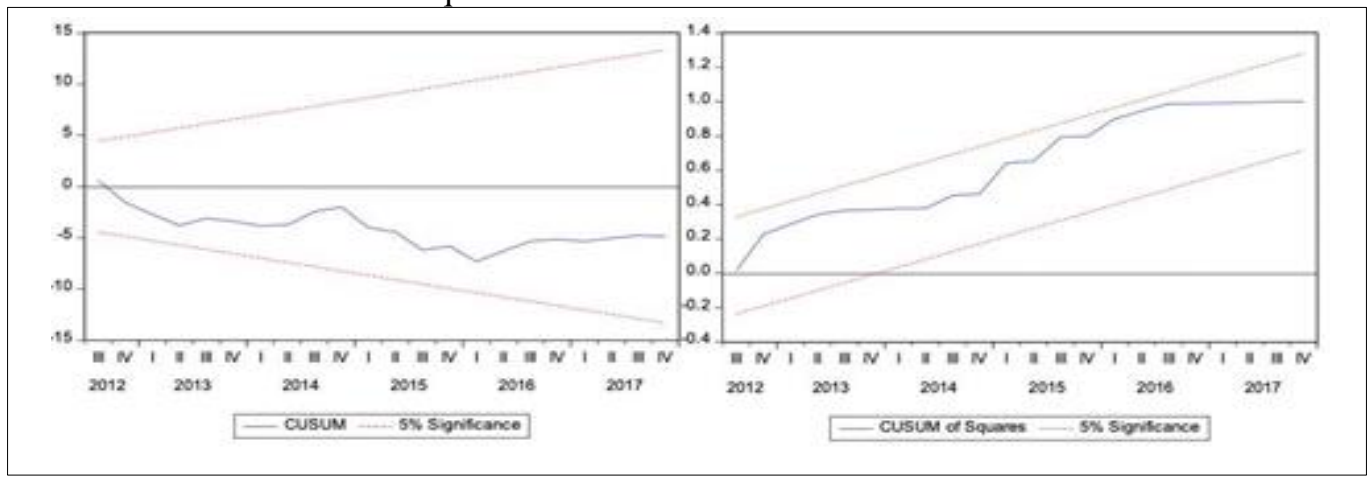

\subsection{VECM Granger Causality}

The results of the Granger causality test, as shown in Table 6, indicate that hot money does not Granger cause the stock market, but oil price does Granger cause hot money. This is in line with the study conducted by Wei et al. (2018). Besides, hot money Granger cause RGDP in a unidirectional way. Zhang et al. (2019) claim that a unidirectional causality mainly focuses on industry output instead of service and agricultural outputs. The importance of hot money could be seen if China is heavily reliant on the industrial sector. In addition, there is no effect between RDGP and stock market. The result is different from the study conducted by Laokulrach (2014) and Antonios (2010) who ascertain that the expansion of the stock market is an alternative technique to contribute funds for investment opportunities, in turn, augmenting economic growth. The results also show that a unidirectional causality was found from RGDP and oil price to inflation that supported by Ahmed et al. (2015). Last but not least, with the expected negative sign, the speed of adjustment of the lagged ECT for the stock market represents a significant long-run causal effect which is consistent with the results of the ARDL. The ECT indicates that the stock market 
performance in China would converge to its equilibrium within 9.89 quarters after the shocks, with an adjustment of $10.11 \%$ per quarter.

Table 6: VECM Granger Causality

\begin{tabular}{ccccccc}
\hline \hline $\begin{array}{c}\text { Dependent } \\
\text { Variable }\end{array}$ & D(LNSM) & D(LNNHM) & D(RGDP) & D(LNOP) & D(LNINF) & ECT (-1) \\
\hline $\mathrm{D}($ LNSM $)$ & - & 1.4948 & 1.7047 & 2.6142 & 1.8905 & -0.1011 \\
$\mathrm{D}(\mathrm{LNNHM})$ & 0.3256 & - & 0.4581 & $5.2061^{*}$ & 2.7504 & -0.0048 \\
$\mathrm{D}(\mathrm{RGDP})$ & 2.2012 & $4.6931^{*}$ & - & 2.9689 & $9.5579 * * *$ & 0.0170 \\
$\mathrm{D}(\mathrm{LNOP})$ & 2.2635 & 4.5805 & 2.2241 & - & 1.2535 & -0.6999 \\
$\mathrm{D}(\mathrm{LNINF})$ & $11.4463^{* * *}$ & 0.0998 & $7.5673^{* *}$ & $7.3676^{* *}$ & - & -0.3003 \\
\hline \hline
\end{tabular}

Notes: $* * * * *$ and $*$ denote the significance at the $1 \%, 5 \%$ and $10 \%$ levels, respectively.

Figure 4: Granger Causality Channels

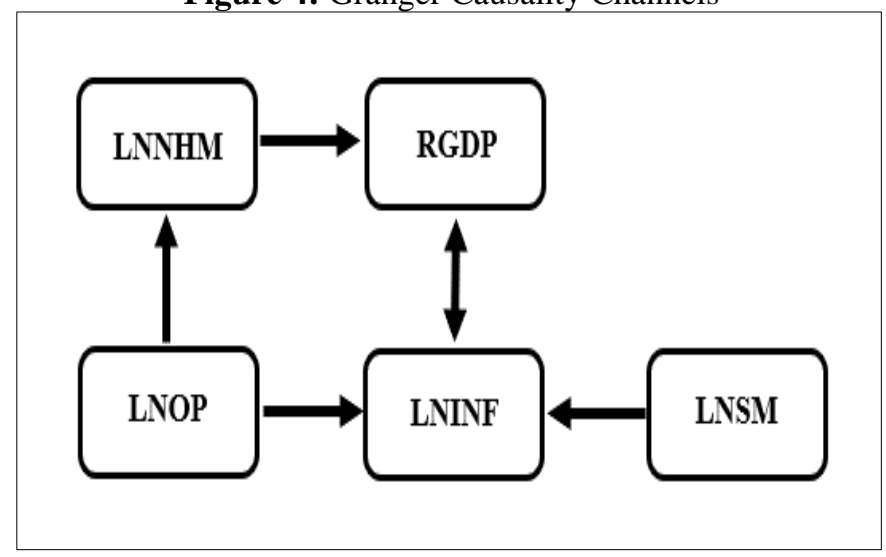

\subsection{Impulse Response Function}

Figure 5 indicates the results of the impulse response function that visualise the destabilisation experienced by the endogenous variables in response to one external standard deviation (SD) shock within other variables. The stock market is found to be significantly responsive to its own shock, in the first quarter it experiences a slight increase but then it continues with a downward trend. Besides, the response of the market to a one standard deviation shock of hot money reveals that there is a cyclical component, as a long-term wave-like pattern occurs. Moreover, the stock market experiences a slow and consistent increase when there is one SD shock given to RGDP.

Besides, the response of the stock market is found to be negative when there is one SD shock given to oil price. Similarly, the response of the stock market from a shock of RGDP indicates aslow and steady decrease in the stock market performance, but after the fourth quarter, it indicates an increase, which is maintained until the tenth quarter. Furthermore, the shocks of all of the variables on the response of the stock market performance are found to experience different types of changes. The oil price experiences a decrease in the first quarter but slowly increases later, whereas, hot 
money experiences a long-term wave-like pattern. Inflation also experiences a trend which is similar to that of hot money.

On the other hand, the response of hot money to its own shocks is significant and remains positive throughout the 10 quarters. Whereas, the response on RGDP also shows that it is significant and positive with an upward trend. The oil price possesses significant and negative responses to its own shocks and experiences a steady decline in trend. However, hot money seems to show a significant and increasing trend during the first three quarters but later experiences a steady negative response until the tenth quarter. For the response of RGDP, it is significant and negative to its own shocks in the ninth and tenth period in the shock of RGDP. Last but not least, significant and negative responses to inflation are found from the shocks of RGDP and stock market.

Figure 5: Impulse Response Function

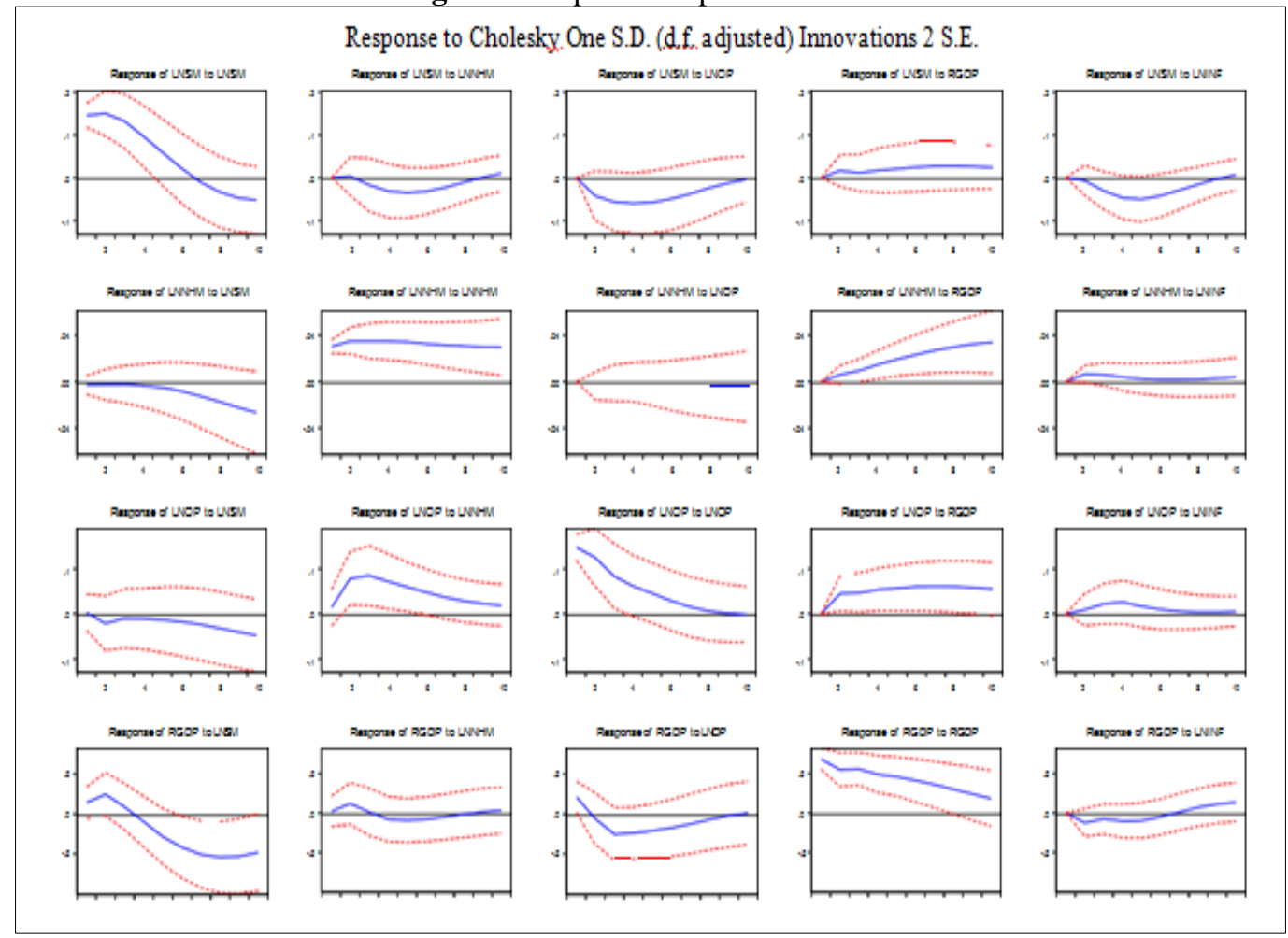

\subsection{Variance Decomposition}

Table 7 shows the results of the variance decomposition analysis (VDC) which separate the variation of each of the endogenous variables into the component shocks to the VECM. The shocks to stock market, in response to a standard deviation of one, show that oil price and inflation rate range greatly from $0 \%$ to $14.43 \%$ and $0 \%$ to $7.51 \%$, respectively. On the other hand, the shocks of 
hot money $(3.72 \%)$ and RGDP $(3.83 \%)$ are found to have contributed only minor effects toward stock market shocks in the discrete time periods.

Moreover, the VDC of hot money indicates that the most significant shock effects come from RGDP, which consist of the highest range (28.96\%) compared to oil price $(0.62 \%)$, inflation rate $(0.76 \%)$ and stock market $(10.06 \%)$, respectively. This can be supported by the causal relationship between hot money and RGDP. Furthermore, the VDC of oil price finds that the shock effects of hot money and RGDP respond greatly to a one standard deviation shock in oil price. This is in line with the finding in the causal relationship between hot money and oil price. In the VDC of RGDP, inflation shocks highly respond to one standard deviation of stock market by $37.07 \%$. Whereas, for the VDC for inflation, the changes in inflation are explained by one standard deviation shock in stock market, hot money, oil price and RGDP with percentages of $19.09 \%, 14.96 \%, 12.98 \%$ and $14.29 \%$, respectively.

Table 7: Variance Decomposition Analysis of Stock Market Performance

\begin{tabular}{ccccccc}
\hline \multicolumn{7}{c}{ Variance Decomposition of LNSM: } \\
\hline Period & S.E. & LNSM & LNNHM & LNOP & RGDP & LNINF \\
1 & 0.1457 & 100.00 & 0.0000 & 0.0000 & 0.0000 & 0.0000 \\
5 & 0.3089 & 77.8153 & 2.6293 & 12.4118 & 1.1677 & 5.9759 \\
10 & 0.3387 & 70.5138 & 3.7233 & 14.4268 & 3.8256 & 7.5105 \\
\hline \multicolumn{7}{c}{ Variance Decomposition of LNNHM: } \\
\hline Period & S.E. & LNSM & LNNHM & LNOP & RGDP & LNINF \\
1 & 0.0303 & 0.8981 & 99.1020 & 0.0000 & 0.0000 & 0.0000 \\
5 & 0.0814 & 0.8839 & 86.4733 & 0.3060 & 10.8213 & 1.5156 \\
10 & 0.1327 & 10.0559 & 59.5928 & 0.6242 & 28.9632 & 0.7639 \\
\hline \multicolumn{7}{c}{ Variance Decomposition of LNOP: } \\
\hline Period & S.E. & LNSM & LNNHM & LNOP & RGDP & LNINF \\
1 & 0.1482 & 0.0426 & 0.8316 & 99.1258 & 0.0000 & 0.0000 \\
5 & 0.2925 & 0.9943 & 26.0640 & 58.9705 & 12.1705 & 1.8007 \\
10 & 0.3397 & 5.7098 & 24.0076 & 44.7210 & 24.0587 & 1.5029 \\
\hline \multicolumn{7}{c}{ Variance Decomposition of the RGDP: } \\
\hline Period & S.E. & LNSM & LNNHM & LNOP \\
1 & 0.7298 & 3.7294 & 0.0765 & 8.5552 & 87.6389 & 0.0000 \\
5 & 1.4156 & 8.9938 & 1.4790 & 10.8034 & 76.6332 & 2.0939 \\
10 & 1.9546 & 37.0669 & 1.0525 & 6.9927 & 52.7806 & 2.1073 \\
\hline \multicolumn{7}{c}{ Variance Decomposition of LNINF: } \\
\hline Period & S.E. & LNSM & LNNHM & LNOP \\
1 & 0.3548 & 0.8926 & 5.6798 & 3.2214 & RGDP & LNINF \\
5 & 0.5457 & 17.5049 & 15.9652 & 10.5001 & 11.8180 & 44.2118 \\
10 & 0.6054 & 19.0904 & 14.9609 & 12.9838 & 14.2911 & 38.6738 \\
\hline \multicolumn{7}{c}{}
\end{tabular}

\section{CONCLUSION AND POLICY IMPLICATIONS}

The results from the ARDL bounds testing cointegration approach reveal that there is a long-run relationship between oil price, economic growth, inflation rate, hot money and stock market performance, except for inflation. Under the nonlinear autoregressive distributed lag (NARDL) model, the results show that an asymmetric effect existed between hot money and the stock market 
performance in China. The significant negative direction of hot money in the NARDL model indicates that a reduction in hot money tends to improve China's stock market performance, while a positive direction is found to have an insignificant effect. Besides, both economic growth and the oil price are positively related to the stock market performance while a negative effect is obtained from inflation.

Consistent with the results of the ARDL and NARDL models, the Granger causality test shows that economic growth does affect hot money. Meanwhile, the impulse response function and variance decomposition reveal that hot money and economic growth significantly respond to the performance of the stock market. This implies that the stock market performance might be affected by hot money through the medium of economic growth. In other words, hot money is found to affect economic growth directly, but rather, by its indirect effect on the performance of the stock market.

Therefore, a better understanding of the significant determinants could contribute to designing appropriate policies and strategies to strengthen China's stock market. The positive impact of oil price on the stock market suggests that shareholders and investors need to be more attentive to the sensitivity of oil price changes to improve their investment decisions. Besides, the stock market is an indicator in shaping national financial wealth. Therefore, policymakers should implement sustainable policies to ensure continued economic growth and stability in the stock market.

Considering the asymmetric effect of hot money on the stock market performance, whereby the alternation has significantly occurred in negative territory, policymakers should create the improved monitoring systems to control the inflows of hot money. Having better control over these cash flows will help to strengthen the confidence of investors and avoid unwanted bubbles in China's stock market. Furthermore, control methods, such as exchange rate appreciation, interest rate reductions and capital control policies are suggested to avert enormous inflows of hot money during inappropriate periods. To overcome the limitations of this study, we recommend using a broader range of data, such as daily or monthly interval data, to increase the accuracy of the model

estimation. Last but not least, researchers could further extend the investigation of the effects of hot money on the stock market performance to other countries by employing panel data analysis.

\section{ACKNOWLEDGEMENT}

This paper was presented at the $21^{\text {st }}$ Malaysian Finance Association Conference 2019, Sunway University, Selangor, Malaysia.

\section{REFERENCES}

Ahmed, S. F., Islam, K. M. Z., \& Khan, M. R. (2015). Relationship between inflation and stock market returns: Evidence from Bangladesh. Journal of Business and Economics, 9(1), 1-12.

Allen, F. (2017). China in 2017: Why Stability - not Growth - Is the Goal. Retrieved February 20 , 2019 from https://knowledge.wharton.upenn.edu/article/china-2017-stability-not-growthgoal/ 
Amadeo, K. (2018). China's Stock Market, Including Shanghai, Shenzhen, and Hong Kong. Retrieved July 15, 2020 from https://www.thebalance.com/china-stock-market-shanghaishenzhen-hong-kong-3305480

Antonios, A. (2010). Stock market and economic growth: An empirical analysis for Germany. Business and Economics Journal, 2010(BEJ-1), 1-12.

Asayesh, H., \& Gharavi, M. Z. (2015). The Impact of Inflation on Stock Price with Panel Data (Case Study: Tehran Stock Exchange). International Journal of Administration and Governance, 1(9), 6-11.

Bai, Z. (2014). Study on the impact of inflation on the stock market in China. International Journal of Business and Social Science, 5(7), 261-271.

Borzykowski, B. (2018). China Is Still the Wildcard in the Stock Market's Wild Ride-Here's Why. Retrieved July 15, 2020 from https:/www.cnbc.com/2018/10/17/china-is-still-the-wildcardin-the-stock-markets-wild-ride.html

Breitung, J., \& Candelon, B. (2006). Testing for short- and long-run causality: A frequency-domain approach. Journal of Econometrics, 132(2), 363-378.

Cai, T., Dang, V. Q. T., \& Lai, J. T. (2016). China's capital and 'Hot' money flows: An empirical investigation. Pacific Economic Review, 21(3), 276-294.

Carp, L. (2012). Can stock market development boost economic growth? Empirical evidence from emerging markets in Central and Eastern Europe. Procedia Economics and Finance, 3, 438444.

Chari, V. V., \& Kehoe, P. J. (2003). Hot money. Journal of Political Economy, 111(6), 1262-1292.

Domowitz, I., Glen, J., \& Madhavan, A. (1997). Market segmentation and stock prices: Evidence from an emerging market. The Journal of Finance, 52, 1059-1085.

Faisal, F., Tursoy, T., \& Berk, N. (2018). Linear and non-linear impact of Internet usage and financial deepening on electricity consumption for Turkey: empirical evidence from asymmetric causality. Environmental Science and Pollution Research, 25(12), 11536-11555.

Farooq, O., \& Ahmed, N. (2018). Does inflation affect sensitivity of investment to stock prices? Evidence from emerging markets. Finance Research Letters, 25, 160-164.

Fickling, D. (2018). Forget Iran. The Real Oil Action is in China. http://www.bloomberg.com/view/articles/2018-05-09/forget-iran-the-real-oil-action-is-inchina

Filis, G., \& Chatziantoniou, I. (2014). Financial and monetary policy responses to oil price shocks: Evidence from oil-importing and oil-exporting countries. Review of Quantitative Finance and Accounting, 42(4), 709-729.

Fuertes, A. M., Phylaktis, K., \& Yan, C. (2016). Hot money in bank credit flows to emerging markets during the banking globalization era. Journal of International Money and Finance, 60, 29-52.

Guo, F., \& Huang, Y., S. (2010). Does "hot money" drive China's real estate and stock markets? International Review of Economics \& Finance, 19(3), 452-466.

Haan, W. J. D. (2011). Impulse Response Function. Retrieved January 10, 2019 from http://econ.lse.ac.uk/staff/wdenhaan/teach/slidesIRF.pdf

Jansen, W. J. (2003). What do capital inflows do? Dissecting the transmission mechanism for Thailand, 1980-1996. Journal of Macroeconomics, 25(4), 457-480.

Kim, D., \& Iwasawa, S. (2017). Hot money and cross-section of stock returns during the global financial crisis. International Review of Economics \& Finance, 50, 8-22. 
Kirankabeş, M. C., \& Başarir, C. (2012). Stock market development and economic growth in developing countries: an empirical analysis for Turkey. International Research Journal of Finance and Economics, 87, 134-146.

Laokulrach, M. (2014). Relationship between stock market and economic development in Thailand: Empirical test of the whole stock market and each industry in 1998-2012. International Journal of Art \& Sciences, 7(1), 235-244.

Lavietes, M. (2018). China Keeps Buying Iranian Oil, and the Trade War Adds a Reason to Defy US Sanctions. Retrieved July 15, 2020 from http://www.cnbc.com/2018/07/23/how-china-can-useiran-oil-sanctions-to-gain-concessions-in-trade-war.html

Lu, C., \& Xin, Z. (2010). Impulse-Response function Analysis: An application to macroeconomy data of China [Master's Thesis, School of Economics and Social Sciences, Hoskolan Dalarna]. http://www.statistics.du.se/essays/D10_Xinzhou_lucao.pdf

Luqman, R., \& Kouser, R. (2018). Asymmetrical linkages between foreign exchange and stock markets: Empirical evidence through linear and non-linear ARDL. Journal of Risk and Financial Management, 11, 51-63.

Lutkepohl, H. (2010). Variance Decomposition. In S. N. Durlauf, \& L. E. Blume (Eds.). Macroeconometrics and Time Series Analysis (1 ${ }^{\text {st }}$ ed., pp. 369-377). Springer Link. https://doi.org/10.1057/9780230280830

Martin, M. F., \& Morrison, W. M. (2008). China's “Hot Money” problems. CRS Report for Congress Order Code RS22921. https://fas.org/sgp/crs/row/RS22921.pdf

Narayan, P. K. (2005). The saving and investment nexus for China: evidence from cointegration tests. Applied economics, 37(17), 1979-1990.

Nazir, M. S., Nawaz, M. M., \& Gilani, U. J. (2010). Relationship between economic growth and stock market development. African Journal of Business Management, 4(16), 3473-3479.

Paraskova, T. (2018). China's Economic Growth Stimulus Could Boodt Oil Demand. Retrieved January 10, 2019 from https://oilprice.com/Energy/Energy-General/Chinas-EconomicGrowth-Stimulus-Could-Boost-Oil-Demand.html

Pearce, D. K., \& Roley, V. V. (1984). Stock prices and economic news (NBER Working Paper No. 1296). National Bureau of Economic Research. https://doi.org/10.3386/w1296

Pesaran, M. H., \& Shin, Y. (1998). An autoregressive distributed-lag modelling approach to cointegration analysis. Econometric Society Monographs, 31, 371-413.

Pesaran, M. H., Shin, Y., \& Smith, R. J. (1999). Pooled mean group estimation of dynamic heterogeneous panels. Journal of the American Statistical, 94(446), 621-634.

Pesaran, M. H., Shin, Y., \& Smith, R. J. (2001). Bounds testing approaches to the analysis of level relationships. Journal of Applied Econometrics, 16(3), 289-326.

Rushe, D. (2018). Stock Market Roiled as US-China Trade Dispute Escalates. https://www.theguardian.com/business/2018/jun/19/stock-markets-latest-fall-trump-chinatrade-war-tariffs

Salim, A., \& Shi, K. (2019). A Cointegration of the exchange rate and macroeconomic fundamentals: The case of the Indonesian Rupiah vis-à-vis currencies of primary trade partners. Journal of Risk and Financial Management, 12, 87-103.

Şentürk, M., Özkan, G. S., \& Akbaş, Y. E. (2014). The relationship between economic growth and stock returns: evidence from Turkey. Doğuş Üniversitesi Dergisi, 15(2), 155-164.

Shanghai Stock Exchange. (2019). SSE Indices System Construction. Retrieved January 10, 2020 from http://english.sse.com.cn/markets/indices/overview/ 
Suharsono, A., Aziza, A., \& Pramesti, W. (2017). Comparison of vector autoregressive (VAR) and vector error correction models (VECM) for index of ASEAN stock price. In AIP Conference Proceedings, 1913(1), 020032-1-020032-9. https://doi.org/10.1063/1.5016666

Tiwari, A. K., Dar, A. B., Bhanja, N., Arouri, M., \& Teulon, F. (2015). Stock returns and inflation in Pakistan. Economic Modelling, 47, 23-31.

Tripathi, V., \& Kumar, A. (2014). Relationship between inflation and stock returns - Evidence from BRICS markets using Panel Co integration test. International Journal of Accounting and Financial Reporting, 4(2), 647-658.

Tsuyuguchi, Y. (2009). The recent flow of "hot money" in China. Bank of Japan Review, 9, 1-7.

Tursoy, T., Faisal, F., Berk, N., \& Shahbaz, M. (2018). How do Stock Prices and Metal Prices Contribute to Economic Activity in Turkey? The Importance of Linear and Non-linear ARDL. (MPRA Paper No. 88899). Munich Personal RePEc Archive. https://mpra.ub.unimuenchen.de/88899/1/MPRA_paper_88899.pdf

Uwubanmwen, A., \& Eghosa, I. L. (2015). Inflation rate and stock returns: Evidence from the Nigerian stock market. International Journal of Business and Social Science, 6(11), 155-167.

Wang, Y., Wu, C., \& Yang, L. (2013). Oil price shocks and stock market activities: Evidence from oil-importing and oil-exporting countries. Journal of Comparative Economics, 41(4), 12201239.

Wei, Y., Yu, Q., W., Liu, J., \& Cao, Y. (2018) Hot money and China's stock market volatility: Further evidence using the GARCH-MIDAS model. Physica A: Statistical Mechanical and its Applications, 498, 923-930.

Wu, H. (2008). 'Hot Money' Causes Serious Problems in China. Retrieved January 10, 2019 from https://www.theepochtimes.com/hot-money-china_1529694.html

Xiao, J., Zhou, M., Wen, F., \& Wen, F. (2018). Asymmetric impacts of oil price uncertainty on Chinese stock returns under different market conditions: Evidence from oil volatility index. Energy Economics, 74, 777-786.

Zhang, Y., Chen, F., Huang, J., \& Shenoy, C. (2019). Hot money flows and production uncertainty: Evidence from China. Pacific-Basin Finance Journal, 57(C), 101070. https://doi.org/10.1016/j.pacfin.2018.09.006

Zheng, X., \& Su, D. (2017). Impacts of oil price shocks on Chinese stock market liquidity. International Review of Economics \& Finance, 50, 136-174. 